\title{
School Governance and Academic Excellence: The Representations of Distinguished Students in an Annual Award of Excellence*
}

\author{
José Augusto Palhares - Leonor Lima Torres
}

Universidade do Minho - Braga - Institute of Education (Portugal)

doi: 10.7358/ecps-2015-011-palh

jpalhares@ie.uminho.pt

leonort@ie.uminho.pt

GOVERNANCE DELLA SCUOLA ED ECCELLENZA SCOLASTICA: LE RAPPRESENTAZIONI DEGLI ALUNNI CHE SI SONO DISTINTI IN UN PREMIO ANNUALE DI ECCELLENZA

\section{Abstract}

Within a research project on "academic excellence in the state school", this paper is a contribution to the sociological reflection on the cultural and organisational characteristics of the school and its relationship with the academic success of students. The data we present stem from a case study underway at a secondary school in the north of Portugal, referring to the universe of students that since 2003 have distinguished themselves for achieving grades equal to or greater than 18 (on a scale of 0 to 20) and have thus been included in the school's Framework of Excellence. From a contextual approach to this educational practice, we focused on the cultural characteristics of the schoollsubject as analytical support for the study of school and non-school dimensions in their mutual connections. To this end, we used the information from document analysis and data collected from a questionnaire survey

* This work is funded by National Funds through FCT - Foundation for Science and Technology under the PTDC/IVC-PEC/4942/2012 project of the research Centre in Education of the University of Minho (CIEd) entitled «Between more and better school: Academic excellence in Portuguese state schools». A preliminary version of this paper was published in Portuguese language in the journal Sociologia da Educação. Revista Luso-Brasileira, Special Issue, 2012. 
administered to more than two-thirds of the students included in the above-mentioned Framework of Excellence. Subsequently, we will use the data from this survey to understand the extent to which academic excellence is perceived as an indivisible social construction of the school's political and organisational matrix, particularly in terms of the educational and teaching guidelines adopted by the management body. We will conclude by questioning the meaning of the school's management policies regarding the emphasis on educational outcomes, with particular focus on the representations of excellent students in the processes of school leadership, teaching organisation, school merit and justice.

Keywords: Academic excellence, Academic path, Leadership, Non-school education, School culture.

\section{THE RESEARCH FRAMEWORK}

Today, competitiveness, excellence and effectiveness of educational systems are important dimensions of the agenda of international education. The Portuguese educational reality has to develop around a fundamental dilemma induced by this agenda: first, the preservation of democratic values of the state educational system (equality, inclusion and citizenship); and second, the promotion of multiple devices of control, monitoring of rsults and resource rationalisation. The institutionalisation of the internal and external evaluation processes of schools, the implementation of a governance model centred on a unipersonal leadership, the publication of rankings, the implementation of an evaluation model of teacher performance are the main structural axes of the Portuguese educational policy (Torres \& Palhares, 2009; Afonso, 2010). Subjected to this strain (more school/ better school), the state school is faced with the difficult task of reconciling two antagonistic demands. In reality, how do schools fulfil their mission? How do they use their margin of relative autonomy to respond to the pressure from the State and the market? What is the matrix of values prevailing in school management practices: the values of excellence and meritocracy, the values of inclusion and "school for all», or the so difficult reconciliation between the two goals? At a time when the Portuguese educational system is still far from having consolidated its democratic function, where we are witnessing a political recentralisation of school management (cfr. Lima, 2009), it is interesting to analyse how schools are responding to this bipolar pressure, redefining their educational mandates.

When going through the international scientific literature, we were able to observe a wide production in several areas, with a prevalence for the 
dimensions of educational policy, school organisation and management and teaching processes. The works on trends and socio-organisational implications of the educational agenda of managerial nature (Ball, 2002), on governance models in the democratic autonomy framework (Barroso, 2003 and 2005; Lima, 2011), on leadership styles (Costa, 2000; Sergiovanni, 2004; Hargreaves \& Fink, 2007; Torres \& Palhares, 2009), on the «school effect» on the production of results (Reynolds, Jones, \& Leger, 1976; Dubet, Cousin, \& Guillemet, 1989; Cousin, 1993; Bressoux, 1994) have multiplied, amongst other relevant topics and authors. More recently, research on the factors that promote student success and academic performance have intensified, especially approaches that emphasise the social, economic and cultural conditions of the families (Lahire, 1995; Ferrand, Imbert, \& Marry, 1999; Nogueira, 2004; Brandão, 2007), leadership styles, school culture (Dumay, 2009) and teaching organisation (Perrenoud, 1984 and 1999; Vasconcellos, 2006). However, the study on "academic excellence» has not generated a significant range of empirical research of reference.

The main aim of this paper lies in understanding the factors involved in the construction process of academic excellence, based on the firm belief that high levels of student performance can only be explained if we consider the network of interdependencies that are established between the school environment and the social and family universe. The development of a predominantly qualitative methodology (case studies) will enable a better understanding on how to build academic excellence, whose most significant dimensions usually escape the perspectives adopted by extensive research. Since it is not a mere study on the academic success of students, our approach will focus on the most successful students of the Portuguese educational system in order to obtain comprehensive views on other concepts, measures and strategies of (individual and collective) agents also involved in the state school project.

In short, we intend to analyse the relationships between the cultural, political and organisational matrix of a state school and the distinguished students' perception of the latter within an annual award of excellence in order to explain their academic performance.

\section{RESEARCH METHODOLOGY}

Taking into account the theoretical guidelines governing this research, we adopted a predominantly qualitative methodology by using a case study, in the assumption of better grasping the trends of the trajectories of excellence, as well as several key factors involved in their daily construction process. The case 
study took place in a secondary school in the north of Portugal - a centenarian institution and legacy of secondary education - that has been granting an annual award of excellence since academic year 2003/2004. Our study focused on the universe of students who were distinguished in the last ten years for achieving an average grade equal to or higher than 18 in their school results.

After obtaining the sociographic profile of about 448 «excellent students", based on the information acquired through the content analysis of their biographical records, we moved, at a later stage, to the presentation of some data collected from a questionnaire survey of a universe of student laureates. 176 surveys were returned - 60 were self-administered in the classical form (paper) and 116 were completed on-line. These surveys are identical, consisting of about 60 questions (270 variables), both of which were adapted to the current academic path and life of the respondents: the first is aimed at students who still attend school, and the second at students enrolled in higher education or that are already working at the time of its completion.

The following data that we submit for further discussion resulted primarily from these two methodological procedures (biographical records of students and questionnaire survey), even though we convened the records from the fieldwork notebook obtained through the observation of activities and school events.

\subsection{Sociographic profile of excellent students}

Since the school established an annual award of excellence in academic year 2003/2004, a progressive increase of students with grades above 18 has been observed. With the exception of academic year 2005/2006, which had similar values to the previous year - associated to the slight decrease in the number of students enrolled in secondary education in that academic year - in the time period under review we observed a significant rise of student laureates, thus representing about $10 \%$ of all students enrolled in the school in recent years (Figure 1).

The most successful students are girls (61\%) and those enrolled in the scientific field of Science and Technology (69.3\%), considered an emblematic area in this school. Even comparing this value to the unbalanced distribution of classes by scientific area (on average, Science and Technology classes represent the triple of other areas), this area remains highlighted at the academic performance level. The school curriculum of these students proves to be rather homogeneous to the extent that almost all students come from middle schools (5th-9th grade) located in the vicinity of this school and the majority have attended a middle school nearby (Figures 2 and 3). 


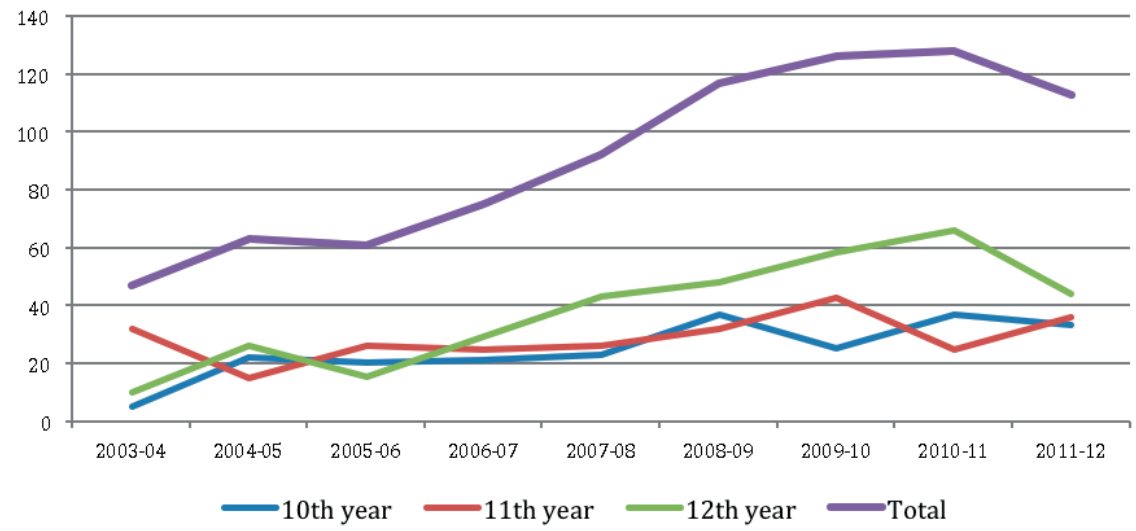

Figure 1. - Evolution of excellent students (2003-2012) (nr. = 415).

Source: lists of students involved in the annual award of excellence (2003-2012).

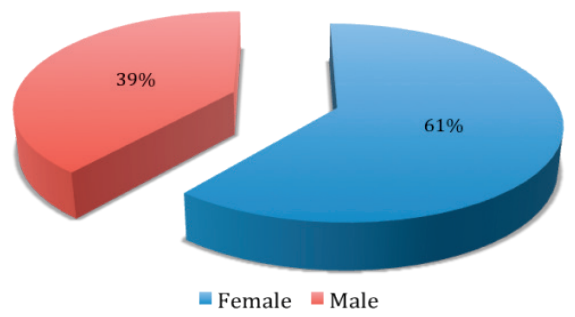

Figure 2. - Gender (nr. = 448).

Source: lists of students involved in the annual award of excellence (2003-2012).

\section{Languages and Humanities}

Socioeconomic Sciences

Science and Technology

Visual Arts
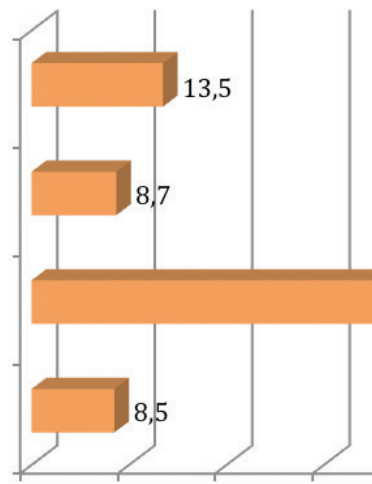

10

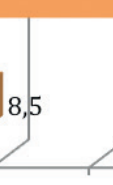

20
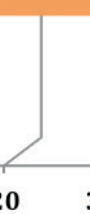

Figure 3. - Scientific area $(n r .=414)$

Source: lists of students involved in the annual award of excellence (2003-2012). 
From the socio-economic characteristics perspective, the majority of these students come from small families: $54.5 \%$ have only one brother or sister and $37.6 \%$ are an only child. Within this scope, we refer to the reduced social support given to these students, noting that only $9 \%$ actually rely on this support, a value well below the overall percentages recorded in the last four years in this school $(33 \%, 37 \%, 25 \%$ and $10 \%$, respectively).

By observing the biographical records of students provided by the school archives, we could have access to the parents' occupations (declared by themselves) and their subsequent aggregation according to the typology of the National Classification of Occupations. If, on the one hand, the obvious is immediately evident, i.e. that a significant proportion of these students' parents $(26.7 \%$ and $28 \%$, respectively) have intellectual and scientific occupations (namely teachers, doctors, lawyers and engineers), on the other, Table 1 also gives us access to other relevant social and professional indicators: the presence of high school performance amongst students whose families have occupations in industry (such as factory workers), commerce, and agriculture and fishery, amongst other economic activities of a lower social status.

Table 1. - Parents'occupations ( $n r .=415)$.

Source: biographical records of students involved in the annual award of excellence (2003-2012).

\begin{tabular}{lcc}
\hline \multicolumn{1}{c}{ ProfEssional GROUPS } & FATHER & MoTHER \\
\hline Armed Forces & 1.0 & 0.0 \\
Senior officials and managers & 2.9 & 2.2 \\
Intellectual and scientific occupations & 26.7 & 28.0 \\
Technicians and associate professionals & 8.2 & 8.2 \\
Clerks and related workers & 8.0 & 8.2 \\
Service workers and shop and market sales workers & 2.9 & 9.2 \\
Skilled agricultural and fishery workers & 1.7 & 0.5 \\
Craft and related trade workers & 8.7 & 1.9 \\
Plant and machinery operators and assemblers & 3.9 & 2.4 \\
Elementary occupations & 8.2 & 6.0 \\
Unspecified entrepreneurs/industrialists & 5.3 & 1.7 \\
Domestic & 0.0 & 11.8 \\
Pensioners $\left(^{*}\right)$ & 0.5 & 0.2 \\
Unemployed $\left(^{*}\right)$ & 1.2 & 3.1 \\
Deceased $\left(^{*}\right)$ & 1.7 & 0.2 \\
Unknown professional status & 19.3 & 16.4 \\
\hline
\end{tabular}

* Last occupation not present in the biographical records. 
Table 2. - Parents' educational background.

Source: biographical records of students involved in the annual award of excellence.

\begin{tabular}{lcc}
\hline \multicolumn{1}{c}{ Educational Background } & $\begin{array}{c}\text { FAther } \\
\text { NR. }=249\end{array}$ & $\begin{array}{c}\text { Mother } \\
\text { NR. }=265\end{array}$ \\
\hline Cannot read or write & 0.0 & 0.0 \\
Elementary school (1st-4th grade) or equivalent & 8.8 & 9.1 \\
Middle school (5th-6th grade) or equivalent & 12.9 & 12.8 \\
Middle school (7th-9th grade) or equivalent & 6.8 & 10.6 \\
Secondary school (10th-12th grade) or equivalent & 19.3 & 14.3 \\
Bachelor degree & 43.0 & 50.5 \\
Graduate degree & 2.4 & 2.6 \\
\hline
\end{tabular}

We can also confirm the existence of distinct relationships between the parents' schooling and academic excellence that go beyond the mere classic relationship with cultural capital. If a group of students whose parents have a higher schooling level ( $45.4 \%$ fathers and $53.1 \%$ mothers) is observable, then the number of families that have at most compulsory schooling (9th grade) (28.5\% fathers and $32.5 \%$ mothers) should also be highlighted. The data presented above show that the distinguished students at this school do seem to contradict the purely reproductive logic attributed to the educational institution. The presence of many «turncoats» (Bourdieu, 1989; Lahire, 1995) deserting a social destiny predetermined by the social and cultural backgrounds of families reminds us of the need to deepen the debate on broader issues on the democratisation of the state school, as well as on the identification of extra- and intra-organisational variables in order to understand the academic performance of students (Table 2).

\subsection{Representations of excellent students on school management and leadership}

Being geographically located in a municipality on the north coast of Portugal, in a city with about 45,000 inhabitants, the secondary school under study currently has great student appeal that surpasses the residential and proximity logic. Although overwhelmingly attended by students of the municipality, it is also sought by students from the neighbouring municipality and other bordering municipalities, and this trend has considerable expression in the context of academic excellence (about 16\% of the distinguished students reside outside the municipality where the school is located). Although coexisting with another secondary school located in the same urban area, the school/ subject of this research has been setting its educational project on values of 
rigour, strictness and quality service, building a prestigious social image and a reiterated academic vocation oriented towards admission into higher education. This has resulted in the construction of a school identity not compatible with other local or regional educational offers. This vision of the school is frequently updated, especially in the discursive, symbolic and ritual domains, although the various meanings of the institution's everyday action permeate it.

We included a question in the survey in order to understand what, according to the distinguished students, contributed most to their admission into this school. Asked to indicate up to 3 reasons, respondents showed a response trend consonant with the above outlined axiological and educational matrix, thus highlighting the "demanding and quality education» and the concern for good preparation for higher education (cfr. Figure 4). If we add the perception of «good learning environment» to these reasons, then we can point out that the appeal of the school tends to be exerted by the social recognition of the institution as a locus for the development of a long-term academic path.

The school/subject is characterised by the stability of the agents and the educational project at management level. The current director of the school took up office in 1993, first as President of the Board (1993-1998) and then as President of the Executive Council (1998-2008), framed in a democratic and collegial governance structure in these last two stages. The terminological changes corresponded to alterations in the administration and management model of schools imposed by the political hierarchy of the Portuguese educational system, which gradually evolved into the current organisational and governing model, enshrining the figure of the director and the unipersonal management logic.

Another reason for school admission School with a good learning environment

School with good conditions Well ranked school

School with an excellent social image Identification with teaching model

School prepares well its students for higher

Demanding and quality school

School near place of residence

I had relatives attending the school My friends were already attending the school

My parents enrolled me in the school

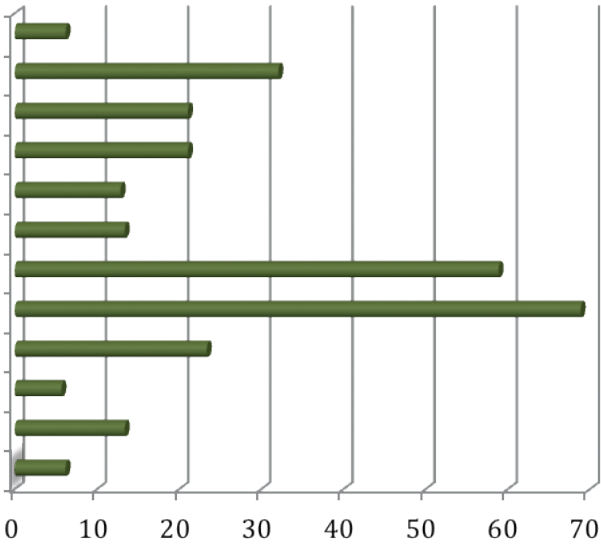

Figure 4. - Reasons that contributed the most to student admission into this school. Maximum of 3 reasons $(n r .=209)$.

Source: questionnaire survey of students involved in the annual award of excellence 2003-2010. 
The two-decade study of this educational institution (cfr. Torres, 1997 and 2004) allowed us to identify a leadership style which is more or less immune to the different configurations of state school governance as imposed by the central government, partly because it was underpinned by the cultural characteristics of the school and was able to re-contextualise the values of a new emerging public management, with a particular emphasis on the production of educational outcomes. Basically, the construction of the educational project, especially at the symbolic level, provided the re-identification of the agents and community with a school idea.

The demand for this school idea is implicit in the construction of propositions which we submitted to the students involved in the annual award of excellence and that can be seen in Table 3 .

Table 3. - School's mode of operation (1 Total disagreement, 5 Total agreement).

Source: questionnaire survey of students involved in the annual award of excellence 2003-2010.

\begin{tabular}{|c|c|c|c|c|c|}
\hline Propositions & NR. & Min. & Max. & MEAN & StD. DeV. \\
\hline This school is a well-organised school & 169 & 1 & 5 & 4.24 & .684 \\
\hline $\begin{array}{l}\text { The main concern is to prepare students } \\
\text { for entry into higher education }\end{array}$ & 168 & 1 & 5 & 4.08 & .797 \\
\hline $\begin{array}{l}\text { This school is the best school } \\
\text { in the region }\end{array}$ & 168 & 1 & 5 & 4.07 & 1.036 \\
\hline $\begin{array}{l}\text { All students have equal opportunities } \\
\text { to succeed }\end{array}$ & 170 & 1 & 5 & 4.06 & 1.025 \\
\hline $\begin{array}{l}\text { This school promotes the study } \\
\text { and the quality of learning }\end{array}$ & 170 & 1 & 5 & 3.97 & .810 \\
\hline $\begin{array}{l}\text { It promotes the learning of democracy } \\
\text { and citizenship }\end{array}$ & 170 & 1 & 5 & 3.97 & .683 \\
\hline $\begin{array}{l}\text { The most important thing is to convey } \\
\text { content and fulfil programmes }\end{array}$ & 170 & 1 & 5 & 3.67 & .882 \\
\hline $\begin{array}{l}\text { Teachers have a high scientific } \\
\text { and teaching preparation }\end{array}$ & 170 & 1 & 5 & 3.66 & .800 \\
\hline $\begin{array}{l}\text { The main mission is to prepare youths } \\
\text { for the labour market }\end{array}$ & 169 & 1 & 5 & 3.49 & 1.018 \\
\hline $\begin{array}{l}\text { The quality of this school is related } \\
\text { to the director's leadership style }\end{array}$ & 167 & 1 & 5 & 3.47 & .943 \\
\hline $\begin{array}{l}\text { Merit and excellence are the maximum } \\
\text { values of the school }\end{array}$ & 167 & 1 & 5 & 3.39 & .987 \\
\hline $\begin{array}{l}\text { This school encourages competition } \\
\text { between students and classes }\end{array}$ & 168 & 1 & 5 & 3.05 & 999 \\
\hline $\begin{array}{l}\text { Only the best students should enter } \\
\text { this school }\end{array}$ & 170 & 1 & 5 & 1.71 & .921 \\
\hline
\end{tabular}


If we hypothetically assume that the administration and management bodies of schools elect, as privileged recipients of their teaching and educational work, the students with this academic profile, then it is also expected that these youths can make a more consistent subjective judgement on the organisational performance of the leaders and values that guide the everyday life of the educational institution.

The propositions are listed in Table 3 in descending order of their average, generally presenting a trend of agreement, except for the last proposition which refutes the idea of discrimination against students with regard to school admission based on academic performance. On the opposite side, the propositions that highlight good school organisation, «vocational guidance» for higher education, the enhancement of a sense of belonging and the democratic nature of school success do actually emerge. Besides other aspects that strengthen the inclusive and socialising function of education, there is also a certain resistance to the acceptance of educational practices of an individualistic and competitive nature, although not refuting them from the outset. But these subjective judgements of respondents horizontally project an image of the school which is very similar to the outcome of the earlier reasons for their choice.

In a complementary exercise, we conducted an exploratory factor analysis (of the main components) based on the propositions of the school's mode of operation. Table 4 gives an account of this statistical procedure, from which 4 components were extracted. They aggregated the response trends of these youths and explain $58.53 \%$ of the deviation. Component 1 , which we shall call "organisational school ethos», reinforces the perceptions previously signalled of an educational institution whose mission is included in the representations of these agents, not only as an educational context of reference, but also as an identity matrix of the educational activity. The remaining components express, respectively, and to a lesser extent, merit and competition (component 2), instructional purpose (component 3 ) and productive logic (component 4).

Finally, challenged to decide on the degree of importance of some aspects related to the promotion of academic excellence, the distinguished students once again associate the intra-school factors with high levels of academic performance. The core generator of academic excellence seems to be defined around the intrinsic dimensions of the teaching relationship and school organisation.

The response trend that becomes evident in Table 5 highlights the so-called «school effect» on academic performance, removing visibility from the extrinsic dimensions of the school, especially those mostly pointed out by the sociological literature in order to understand the educational phenomenon. The social origins, family participation and even involvement in extracurricular activities do not seem important for these students in order to achieve academic excellence. 
Table 4. - Rotated Component Matrix a (PCA) «School's Mode of Operation». Source: questionnaire survey of students involved in the annual award of excellence 2003-2010.

\begin{tabular}{|c|c|c|c|c|}
\hline \multirow[t]{2}{*}{ Propositions } & \multicolumn{4}{|c|}{ COMPONENTS } \\
\hline & 1 & 2 & 3 & 4 \\
\hline This school promotes the study and the quality of learning & .812 & & & \\
\hline This school is a well-organised school & .758 & & & \\
\hline This school is the best school in the region & .722 & & & \\
\hline It promotes the learning of democracy and citizenship & .699 & & & \\
\hline Teachers have a high scientific and teaching preparation & .655 & & & \\
\hline All students have equal opportunities to succeed & .633 & & .322 & \\
\hline $\begin{array}{l}\text { The quality of the school is related to the leadership style } \\
\text { of the director }\end{array}$ & .529 & & & \\
\hline Merit and excellence are the maximum values of this school & & .758 & & \\
\hline Only the best students should enter this school & & .721 & & \\
\hline $\begin{array}{l}\text { This school encourages competition between students } \\
\text { and classes }\end{array}$ & & .651 & & .379 \\
\hline $\begin{array}{l}\text { The main concern is to prepare students for entry into higher } \\
\text { education }\end{array}$ & & & .767 & \\
\hline $\begin{array}{l}\text { The most important thing is to convey content and fulfil } \\
\text { programmes }\end{array}$ & & & .760 & \\
\hline The main mission is to prepare youths for the labour market & & & & .832 \\
\hline Eigenvalues & 3.489 & 1.663 & 1.359 & 1.098 \\
\hline Explained Deviation (\%) & 26.842 & 212.792 & 10.451 & 8.446 \\
\hline
\end{tabular}

Extraction method: Principal component analysis.

Rotation method: Varimax with Kaiser normalisation.

${ }^{a}=$ Rotation converged in 5 iterations.

Whether the respondents' views are naïve or not, which we shall attempt to clear up at a later stage of this study, what is certain is that the centrality of the school environment, organisation mode, teacher quality and leadership style, amongst other variables, seem to converge towards the understanding that the academic performance of these students is also a result of their experience as school agents framed in a particular educational institution. 
Table 5. - Aspects in promoting academic excellence (1 Least important; 5 Most important). Source: questionnaire survey of students involved in the annual award of excellence 2003-2010.

\begin{tabular}{|c|c|c|c|c|c|}
\hline & NR. & Min. & Max. & MEAN & StD. DeV. \\
\hline Teacher qualities & 170 & 1 & 5 & 4.69 & .646 \\
\hline Teaching environment of the school & 169 & 1 & 5 & 4.41 & .659 \\
\hline School organisation & 170 & 1 & 5 & 4.09 & .768 \\
\hline Educational project of the school & 169 & 1 & 5 & 4.05 & .808 \\
\hline $\begin{array}{l}\text { Leadership and management style } \\
\text { of the school }\end{array}$ & 169 & 1 & 5 & 3.92 & .886 \\
\hline $\begin{array}{l}\text { Physical and material conditions } \\
\text { of the school }\end{array}$ & 170 & 1 & 5 & 3.83 & .884 \\
\hline Intellectual characteristics of the students & 170 & 1 & 5 & 3.71 & .994 \\
\hline Involvement of parents/guardians & 168 & 1 & 5 & 3.63 & 1.031 \\
\hline Class composition & 170 & 1 & 5 & 3.50 & .944 \\
\hline $\begin{array}{l}\text { Participation in clubs, projects } \\
\text { and extracurricular activities }\end{array}$ & 167 & 1 & 5 & 2.91 & 1.118 \\
\hline $\begin{array}{l}\text { Social and cultural background } \\
\text { of students }\end{array}$ & 168 & 1 & 5 & 2.37 & 1.108 \\
\hline
\end{tabular}

\section{CONCLUSiON}

The points of analysis laid out above are merely an opportunity to reflect on the academic excellence phenomenon in the state school; an issue that has been absent in the research concerns of social sciences and educational sciences, possibly more connected with other agendas of educational policy and daily management of various educational systems. As this study is still in progress, as part of a broader research project, the trends are necessarily preliminary ones and still lack critical and interpretive substance, which does not, however, alter the fact that one can already capture some contours of the phenomenon/subject in question. In this sense, the fact that many Portuguese state schools adopt the practice of student academic distinction, whether in a ceremonial context or in the establishment of an annual award of excellence, is in itself an indicator of the strain running through the governance of educational institutions. On the one hand, the compliance with the democratic mandate of the universal project of the state school, with a view to equal opportunities in its multiple meaning and the integration of 
cultural diversity in the daily dynamics of the school; on the other hand, the requirement of accountability focused on results, which submits the educational process to a competitive and performing logic, much like the ubiquitous managerial agenda of New Public Management.

The advent of a school organisational model, which abandoned the collegial logic and replaced it with unipersonal leadership processes focused on the figure of the school director and middle management staff (who are now appointed, but used to be elected), responds to new regulatory policies and education control, which have promoted performance evaluation and monitoring mechanisms of the state school, with a particular focus on success rates and school achievement. The increasing implementation of academic distinction practices (frameworks of excellence, competitions and merit awards, amongst others) can be inscribed in the attempt of some schools, within the relative autonomy they have, to contextually respond to this tension between more school / better school. In a growing diversification of the educational offering in the state school setting - from regular courses to technical and professional proposals, from educational and training projects for youths to the recovery of interrupted adult school paths (New Opportunities Centres) - the option towards the institutionalisation of an annual award of excellence may be acknowledged, on the one hand, as a strategy for academic distinction and for a certain elitism of education, and, on the other, as a reference to «best practices» either within the institution or for the local and regional community, or even for other schools and school groupings of the state educational system. Finally, at this point, we are urged to ask: what is the role of academic distinction practices in the construction of democratic citizenship?

From a student's point of view, the organizational factors hold a central place in the promotion of academic excellence. The importance of schoolwork and organizational and educational management strategies in the development of a culture centered on results, to the detriment of household socio-cultural factors, is clearly recognized. The opinion given by students seems to highlight the importance of the so-called «school effect» by stating that the teachers, the pedagogical climate, and the organization of the school, as well as the educational project and the leadership style, are the reasons that allow them to achieve academic excellence. The intellectual characteristics of the students, the influence of their families, the involvement in extra-curricular activities, and the social and cultural backgrounds of the families take second place as if, according to the researcher, the empirical and theoretical capital of the Sociology of Education no longer made sense by emphasizing these representations. However, as noted before, the conjugation of socialization for excellence in a social and culturally meaningful 
background and the assumption that these young people have of the ideal type of student, within an educational organization that transforms them into references of the pedagogical action, lead us to conclude that governance practices of the school where the study took place, as well as in other public Portuguese schools that are currently being studied, tend to build performative ideas that overlap the rising individuation logic in society. Ultimately, in several Portuguese schools the promotion of academic excellence results from an emulation effect in which they were involved, mainly by public education policies that have been developing a (quasi) educational market. And all this at the expense of the belief that many students and families place in successful educational paths and strategies.

\section{REFERENCES}

Afonso, A. (2010). Gestão, autonomia e accountability na escola pública portuguesa: breve diacronia. Revista Brasileira de Política e Administração da Educação, 26(1), 13-30.

Ball, S. (2002). Reformar escolas / reformar professores e os terrores da performatividade. Revista Portuguesa de Educação, 15(2), 3-23.

Barroso, J. (2003). Factores organizacionais da exclusáo escolar. A inclusáo exclusiva. In D. Rodrigues (Coord.), Perspectivas sobre a inclusão. Da educação à sociedade (pp. 25-36). Porto: Porto Editora.

Barroso, J. (2005). Políticas educativas e organização escolar. Lisboa: Universidade Aberta.

Bourdieu, P. (1989). La distinction. Critique social du jugement. Paris: Les Éditions de Minuit.

Brandão, Z. (2007). A produção das elites escolares: escolas, famílias e cultura. Caderno CRH, 20(49), 15-22.

Bressoux, P. (1994). Les recherches sur les effets-écoles et les effets-maitres. Revue Française de Pédagogie, 98, 91-137.

Costa, J. A. (2000). Liderança nas organizaçôes: revisitando teorias organizacionais num olhar cruzado sobre as escolas. In J. A. Costa, A. N. Mendes, \& A. Ventura (Coords.), Liderança e estratégia nas organizaçōes escolares (pp. 15-33). Aveiro: Universidade de Aveiro.

Cousin, O. (1993). L'effet établissement. Construction d'une problématique, Revue Française de Pédagogie, 34, 395-419.

Dubet, F., Cousin, O., \& Guillemet, J.-P. (1989). Mobilisation des établissements et performances scolaires: le cas des colléges. Revue Française de Sociologie, 30, 235-256. 
Dumay, X. (2009). Origins and consequences of schools' organizational culture for student achievement. Educational Administration Quarterly, 45(4), 523-555.

Ferrand, M., Imbert, F., \& Marry, C. (1999). L'ecellence scolaire: une affaire de famille. Paris: L'Harmattan.

Hargreaves, A., \& Fink, D. (2007). Liderança sustentável. Porto: Porto Editora.

Lahire, B. (1995). Tableaux de familles - Heurs et malheurs scolaires en milieux populaires. Paris: Seuil - Gallimard.

Lima, L. (2009). A democratização do governo das escolas públicas em Portugal. Sociologia, 19, 227-253.

Lima, L. (2011). Administraçâo escolar: estudos. Porto: Porto Editora.

Nogueira, M. A. (2004). Favorecimento económico e excelência escolar: um mito em questão. Revista Brasileira de Educação, 26, 133-144.

Perrenoud, P. (1984). La fabrication de l'excellence scolaire. Du curriculum aux pratiques d'évaluations. Genève - Paris: Librairie Droz.

Perrenoud, P. (1999). Avaliação: da excelência à regulação das aprendizagens - Entre duas lógicas. Porto Alegre: Artes Médicas Sul.

Reynolds, D., Jones, D., \& St. Leger, S. (1976). Schools do make a difference. New Society, 37, 223-225.

Sergiovanni, T. (2004). O mundo da liderança. Desenvolver culturas, práticas e responsabilidade pessoal nas escolas. Porto: Edições ASA.

Torres, L. L. (1997). Cultura organizacional escolar. Representaçôes dos professores numa escola portuguesa. Oeiras: Celta.

Torres, L. L. (2004). Cultura organizacional em contexto educativo. Sedimentos culturais e processos de construção do simbólico numa escola secundária. Braga: Instituto de Educação e Psicologia da Universidade do Minho.

Torres, L. L., \& Palhares, J. A. (2009). Perfis de liderança e escola democrática. Revista Lusófona de Educação, 14, 77-90.

Vasconcellos, M. D. (2006). O trabalho pedagógico na construção social da excelência académica. Educação and Sociedade, 27(97), 1089-1112.

\section{Riassunto}

Inserito nell'ambito di un progetto di ricerca sull'"eccellenza scolastica nella scuola pubblica», questo lavoro costituisce un contributo per la riflessione sociologica sulle specificità culturali e organizzative della scuola e sulla sua relazione con il successo accademico degli alunni. I dati che presentiamo provengono da uno studio di caso in corso in una scuola secondaria del nord del Portogallo, che si riferisce all'universo degli alunni che dal 2003 fino ad oggi si sono distinti per risultati scolari pari o superiori a 18 punti (in una scala da o a 20) e sono stati perciò inclusi nel Quadro di Eccellenza di questa scuola. A partire da 
un approccio contestualizzato a questa pratica educativa, abbiamo considerato le specificità culturali della scuola, oggetto dello studio, come supporto analitico per lo studio delle dimensioni scolari e non scolari nelle loro reciproche articolazioni. A questo scopo abbiamo utilizzato le informazioni provenienti da analisi documentate e dai dati raccolti da un questionario di rilevazione somministrato a più dei due terzi degli alunni che fanno parte del menzionato Quadro di Eccellenza. Abbiamo esaminato i dati di questa indagine per capire fino a che punto l'eccellenza scolastica è percepita come una costruzione sociale non dissociabile dalla matrice politica e organizzativa della scuola, in particolare per quanto riguarda gli orientamenti educativi e pedagogici adottati dall'organo di direzione. Concluderemo problematizzando sul senso delle politiche di gestione della scuola che enfatizzano $i$ risultati scolastici, con una particolare attenzione alle descrizioni degli studenti che eccellono negli ambiti della leadership, dell'organizzazione didattica, del merito e della giustizia.

Parole chiave: Cultura organizativa scolastica, Eccellenza accademica, Educazione non scolastica, Leadership, Percorsi scolari. 